(C) 2014

Курцев В. О., кандидат сільськогосподарських наук

Кіровоградська державна сільськогосподарська дослідна станція НААН

\title{
АГРОМЕТЕОРОЛОГІЧНЕ ОБГРУНТУВАННЯ СТРОКІВ СІВБИ РІПАКУ ОЗИМОГО В СТЕПОВІЙ ЗОНІ УКРАЇНИ
}

\section{Рецензент - кандидат сільськогосподарських наук І. М. Семеняка}

Дослідженнями встановлено, щз значне випадання рослин ріпаку озимого в зимовий період спричинює низка факторів: надмірний розвиток сходів у осінній період, відсутність добре розвиненої кореневої системи тощо. У зв'язку з иим значну увагу варто надавати строкам сівби культури. 3 иієї точки зору, найкращчим вважають той строк сівби, який забезпечить оптимальний розвиток рослин протягом осінньої вегетаиії. Вибір строку сівби повинен бути індивідуальним як для зони вирощування, так $і$ для умов кожного конкретного господарства. Основою у прийнятті рішення повинні стати багаторічні спостереження за температурними показниками, частотою, кількістю та характером випадання опадів як у передпосівний період, так $і$ в період появи сходів $і$ розвитку рослин, дат припинення вегетаиії рослин. Найбільш оптимальними строками сівби ріпаку озимого в Степовій зоні України є строки з 25 серпня по 5 вересня, допустимо оптимальними - з 20 серпня по 10 вересня. Датою верхнього допустимого порогу оптимального строку сівби ріпаку озимого є 510 вересня. Лімітуючий фактор у такому діапазоні наявність вологи в трунті та випадання ефективних опадів у даний період.

Ключові слова: ріпак озимий, строки сівби, ефективні температури, кількість опадів, оптимальні пороги строків сівби.

Постановка проблеми. Ріпак за останнє десятиріччя зміцнив свої конкурентні позиції на світовому ринку: суттєво збільшилися валові збори насіння, розширилися ринки збуту, продукти його переробки досягли досить високого рівня.

Література, в якій описано поради з технологій вирощування ріпаку озимого (якій понад 15 років і більше), в переважній своїй більшості містить інформацію не про конкретну зону чи регіон, в якому вирощується культура, а загалом, - там не враховано особливості сучасних сортів і гібридів, кліматичні зміни, що відбулися, сучасні знаряддя обробітку грунту й сівалки, зміни ротацій культур у нових, переважно п'ятипільних сівозмінах, та ін. Рекомендаційні поради деяких буклетів іноземних насінницьких компаній не пристосовані до грунтово-кліматичних і територіально-рельєфних умов України. За таких умов агроном не завжди може вчасно зорієнтуватися й підібрати саме ті строки сівби, які в конкретних умовах його господарства забезпечать повну реалізацію біологічного потенціалу сучасних сортів і гібридів ріпаку озимого, оптимальний розвиток рослин протягом осінньої вегетації та дадуть можливість отримати найвищий врожай і в результаті отримати високорентабельний прибуток.

Вивчення впливу факторів середовища (температурного, світлового режиму, вологості, складу та особливостей грунту, тощо) на продуктивність ріпаку дадуть змогу визначити шляхи підвищення продуктивності даної культури, прогнозувати врожайність в умовах регіону.

Аналіз основних досліджень і публікацій, у яких започатковано розв'язання проблеми. Посівні площі під ріпаком у світі становлять 2224 мільйонів гектар, у Європі ця культура займає майже 4 млн га. В Україні ріпак почали інтенсивно вирощувати лише в останні $10-15$ років. За період 1990-2010 років посівні площі ріпаку збільшились у 12 разів, а валовий збір у 14,4 разу. Найменші посівні площі ріпаку в Україні були в 1970 році - 2 тис. га, а піковим видався 2008 рік, коли фактичні площі ріпаку озимого становили 1,5 млн га, - за даним показником Україна вийшла на перше місце в Європі. В подальшому площі посіву ріпаку озимого скоротилися на 37,5-39,6 \% порівняно з 2008 роком [2-4].

Розширення площ під посівами ріпаку насамперед пов'язано з тим, що він, з огляду агротехніки, вважається цінним попередником для інших культур. Вирощування зернових після ріпаку збільшує врожайність на 3-4 ц/га, що фактично без додаткових витрат підвищує ефективність усього рослинництва. Особлива цінність ріпаку в тому, що завдяки розвинутій і глибоко проникаючій у грунт кореневій системі він засвоює нітрати, запобігаючи їхньому попаданню в грунтові води [1].

Ріпак має чимало агротехнічних та економічних переваг порівняно з іншими сільськогосподарськими культурами й водночас належить до ризикованих культур. За останні три роки в Україні спостерігалося різке зменшення площ посіву ріпаку озимого; причиною цього є відсут- 


\section{СІЛЬСЬКЕ ГОСПОДАРСТВО. РОСЛИННИЦТВО}

ність опадів у літньо-осінній період і недостатні запаси продуктивної вологи в грунті для отримання вирівняних та дружніх сходів. У зв'язку 3 цим сільськогосподарські товаровиробники (нерідко 3 метою зменшення ризиків) обмежують площі посіву даної рентабельної культури [2].

Дослідженнями встановлено, що значне випадання рослин ріпаку озимого в зимовий період спричинює низка факторів: надмірний розвиток сходів у осінній період, відсутність добре розвиненої кореневої системи тощо. У зв'язку з цим значну увагу варто приділяти строкам сівби. 3 цієї точки зору найкращим вважають той строк сівби, який забезпечить оптимальний розвиток рослин протягом осінньої вегетації. Господарства різних регіонів України сівбу ріпаку озимого проводять (залежно від зони вирощування) 3 1 серпня по 20 вересня [1-3].

Вибір строку сівби повинен бути індивідуальним як для зони вирощування, так i для умов кожного конкретного господарства, а за основу прийняття рішення повинні братися багаторічні спостереження за температурними показниками, частотою, кількістю й характером випадання опадів як у передпосівний період, так і в період появи сходів і розвитку рослин, дат припинення вегетації рослин.

Мета досліджень. У зв'язку 3 цим нами в умовах північної частини степової зони України проводилися дослідження впливу факторів середовища та агротехнічних заходів на морфобіологічні показники й урожайність ріпаку озимого.

Завданнями досліджень передбачалося встановити оптимальні для регіону строки сівби ріпаку озимого на підставі багаторічного аналізу сум активних температур періоду вегетації культури та суми ефективних опадів.

Матеріали і методи досліджень. Дослідження проводилися на землях дослідних господарств Кіровоградської КДГДС НААН. Для обгрунтування вибору оптимальних строків сівби використовували дані польових дослідів, закладених на полях Кіровоградської державної сільськогосподарської дослідної станції НААН, і результати аналізу метеоданих за 20002013 роки. Висівали ріпак озимий вітчизняного сорту Сенатор люкс, високорослий гібрид Extend та низькорослий гібрид DK Secure кампанії Moнсанто. Норма висіву для сорту - 1,0 млн схожих насінин на 1 га, для гібридів - 0,5. Висівали ріпак у 4 терміни: 15-20 серпня; 25-31 серпня; 1-10 вересня; 10-15 вересня.

Результати досліджень. За результатами досліджень найбільш оптимальними строками сівби ріпаку озимого в степовій зоні - зоні недоста- тнього зволоження - $є$ строки сівби, що припадають на останню п’ятиденку серпня - першу п'ятиденку вересня.

Для сортів, які менш схильні до переростання, посів починається раніше; для гібридів (особливо зі швидким розвитком) - iз затримкою до третьої декади серпня - першої декади вересня. Оптимальний строк сівби ріпаку озимого - за 15-25 днів до оптимальних термінів сівби озимих колосових культур відповідно до агрокліматичної зони. У виборі оптимальних строків сівби ріпаку озимого в регіоні основною вимогою $\epsilon$ нормальний розвиток рослин перед входженням у зиму. Протягом 60-80 днів від появи сходів до припинення вегетації із сумою температур 600$800{ }^{0} \mathrm{C}$, на основі багаторічних спостережень i аналізу бази метеорологічних даних за 20002013 рр., було визначено календарні дати виконання даних умов (табл. 1).

Так, на основі аналізу таблиці 1 видно, що за календарними датами оптимальні показники 3 сумою температур $800{ }^{0} \mathrm{C}$ забезпечувалися переважно в I-II пентаді вересня за припинення вегетації з 31 жовтня до 26 листопада, а в посушливих умовах 2003, 2011 років - в останній пентаді серпня за припинення вегетації з 25 та 5 жовтня відповідно.

Необхідним є визначення нижнього та верхнього порогів оптимального строку сівби ріпаку озимого - дату, коли необхідно розпочинати сівбу, і дату, коли строки переходять у пізні.

За сприятливих умов зволоження насіння ріпаку проростає через 4-5 днів, сходи з'являються через 7-10 днів від дати сівби. Математичні підрахунки свідчать про нижній поріг оптимальних строків - 20 серпня. За зміщення строків сівби на більш ранні з вищою сумою ефективних температур понад $1000{ }^{\circ} \mathrm{C}$ виникає загроза переростанню рослин ріпаку озимого за достатнього зволоження чи недоотримання сходів - за посушливих умов.

Найважливішим у виборі строків сівби є фактор вологозабезпечення. Поскільки терміни підготовки грунту та сівби ріпаку озимого припадають на посушливий період кінця літа, коли запаси вологи в посівному шарі грунту незначні, а ріпак як дрібно насіннєва культура висівається на глибину 2-3 см, основним джерелом надходження води $є$ атмосферні опади.

Нами було проведено аналіз випадання опадів у період висівання ріпаку озимого в степовій зоні України - серпень-вересень 2000-2013 років (табл. 2).

Аналіз проводився в розрізі п'ятиденок (пентад) та подекадно з вичлененням частки ймовір- 


\section{СІЛЬСЬКЕ ГОСПОДАРСТВО. РОСЛИННИЦТВО}

ності випадання опадів. Як свідчать результати аналізу, найбільш ймовірним є очікування опадів у III декаді серпня - 92,2 \%, а в розрізі пентад i3 25 по 31 серпня, коли ймовірність випадання ефективних опадів - 69,2\%. Даний факт і $є$ вирішальним в обгрунтуванні вибору III декади серпня як оптимального строку сівби, поскільки за таких умов в дев'яти 3 тринадцяти досліджуваних роках можна тримати дружні сходи.

Зміщення строків на більш ранні, коли ймовірність випадання опадів у цей час знаходиться в межах 30-38 \%, а 313 досліджуваних років лише в 4-5 були ефективні опади понад 5 мм, є недоцільним.

\section{1. Сума ефективних $\left({ }^{\circ} \mathrm{C}\right)$ до припинення вегетації ріпаку озимого}

(за даними метеопосту Кіровоградської ДСГДС НААН)

\begin{tabular}{|c|c|c|c|c|c|c|c|c|}
\hline \multirow{2}{*}{ Рік } & \multirow{2}{*}{ Місяць } & \multicolumn{6}{|c|}{ Числа } & \multirow{2}{*}{$\begin{array}{c}\text { Дата } \\
\text { припинення } \\
\text { вегетації }\end{array}$} \\
\hline & & 1 & 5 & 10 & 15 & 20 & 25 & \\
\hline \multirow{2}{*}{2000} & серпень & 1457 & 1340 & 1241 & 1129 & 1029 & 938 & \multirow{2}{*}{6.11} \\
\hline & вересень & 818 & 726 & 629 & 560 & 490 & 395 & \\
\hline \multirow{2}{*}{2001} & серпень & 1617 & 1498 & 1365 & 1253 & 1125 & 991 & \multirow{2}{*}{14.11} \\
\hline & вересень & 885 & 794 & 707 & 619 & 530 & 447 & \\
\hline \multirow{2}{*}{2002} & серпень & 1526 & 1408 & 1301 & 1190 & 1083 & 968 & \multirow{2}{*}{04.11} \\
\hline & вересень & 828 & 711 & 614 & 538 & 465 & 391 & \\
\hline \multirow{2}{*}{2003} & серпень & 1722 & 1350 & 1234 & 1131 & 1010 & 889 & \multirow{2}{*}{25.10} \\
\hline & вересень & 744 & 665 & 595 & 516 & 436 & 358 & \\
\hline \multirow{2}{*}{2004} & серпень & 1608 & 1502 & 1399 & 1296 & 1188 & 1083 & \multirow{2}{*}{16.11} \\
\hline & вересень & 947 & 848 & 775 & 692 & 593 & 515 & \\
\hline \multirow{2}{*}{2005} & серпень & 1550 & 1418 & 1313 & 1214 & 1093 & 983 & \multirow{2}{*}{6.11} \\
\hline & вересень & 859 & 772 & 672 & 569 & 489 & 412 & \\
\hline \multirow{2}{*}{2006} & серпень & 1604 & 1478 & 1354 & 1230 & 1110 & 998 & \multirow{2}{*}{21.11} \\
\hline & вересень & 888 & 812 & 730 & 646 & 69 & 478 & \\
\hline \multirow{2}{*}{2007} & серпень & 1580 & 1464 & 1345 & 1229 & 1095 & 946 & \multirow{2}{*}{7.11} \\
\hline & вересень & 828 & 727 & 638 & 561 & 486 & 435 & \\
\hline \multirow{2}{*}{2008} & серпень & 1642 & 1517 & 1402 & 1263 & 1131 & 1010 & \multirow{2}{*}{11.11} \\
\hline & вересень & 893 & 791 & 664 & 598 & 490 & 406 & \\
\hline \multirow{2}{*}{2009} & серпень & 1497 & 1375,4 & 1282,5 & 1177,3 & 1070,8 & 977,8 & \multirow{2}{*}{31.10} \\
\hline & вересень & 840,9 & 751,6 & 661,3 & 558 & 479,3 & 395 & \\
\hline \multirow{2}{*}{2010} & серпень & 1793 & 1638,9 & 1481,8 & 1332,4 & 1208,5 & 1091,9 & \multirow{2}{*}{25.11} \\
\hline & вересень & 967,5 & 881,3 & 807,4 & 709,1 & 619,2 & 551,9 & \\
\hline \multirow{2}{*}{2011} & серпень & 1360,3 & 1260,1 & 1146,5 & 1031,6 & 926,7 & 825 & \multirow{2}{*}{05.10} \\
\hline & вересень & 701 & 602 & 518,5 & 415,5 & 329,2 & 244,1 & \\
\hline \multirow{2}{*}{2012} & серпень & 1717,8 & 1575,6 & 1440,8 & 1345 & 1246,5 & 1148 & \multirow{2}{*}{14.11} \\
\hline & вересень & 1028,7 & 922,3 & 837,6 & 739,3 & 651,1 & 566,5 & \\
\hline 2013 & серпень & 1554,7 & 1445,2 & 1316,3 & 1183,7 & 1066,9 & 952,6 & 2611 \\
\hline 2013 & вересень & 854,5 & 773,6 & 705,8 & 602,4 & 550 & 480,8 & 20.11 \\
\hline
\end{tabular}


СІЛЬСЬКЕ ГОСПОДАРСТВО. РОСЛИННИЦТВО

\section{2. Аналіз ймовірності випадання ефективних опадів у розрізі пентад і декад}

\begin{tabular}{|c|c|c|c|c|c|c|c|c|c|c|c|c|}
\hline \multirow{4}{*}{ Роки } & \multicolumn{12}{|c|}{ Місяці } \\
\hline & \multicolumn{6}{|c|}{ серпень } & \multicolumn{6}{|c|}{ вересень } \\
\hline & \multicolumn{12}{|c|}{ пентада } \\
\hline & 1 & 2 & 3 & 4 & 5 & 6 & 1 & 2 & 3 & 4 & 5 & 6 \\
\hline 2000 & 0 & 0 & 0 & 0 & 0 & 1 & 0 & 1 & 0 & 1 & 1 & 1 \\
\hline 2001 & 1 & 0 & 0 & 0 & 0 & 1 & 1 & 1 & 1 & 0 & 0 & 1 \\
\hline 2002 & 1 & 1 & 1 & 1 & 1 & 1 & 0 & 0 & 1 & 1 & 1 & 1 \\
\hline 2003 & 1 & 0 & 1 & 0 & 1 & 0 & 1 & 0 & 0 & 0 & 0 & 0 \\
\hline 2004 & 1 & 1 & 0 & 0 & 0 & 0 & 0 & 1 & 0 & 0 & 1 & 1 \\
\hline 2005 & 0 & 1 & 1 & 0 & 0 & 1 & 0 & 0 & 1 & 1 & 0 & 0 \\
\hline 2006 & 0 & 0 & 1 & 0 & 1 & 1 & 1 & 1 & 0 & 0 & 1 & 1 \\
\hline 2007 & 1 & 1 & 1 & 1 & 0 & 1 & 0 & 1 & 1 & 1 & 1 & 1 \\
\hline 2008 & 0 & 0 & 0 & 0 & 0 & 1 & 0 & 0 & 1 & 1 & 1 & 0 \\
\hline 2009 & 0 & 0 & 0 & 0 & 0 & 1 & 1 & 1 & 0 & 0 & 1 & 0 \\
\hline 2010 & 0 & 0 & 0 & 1 & 0 & 1 & 1 & 1 & 0 & 0 & 1 & 1 \\
\hline 2011 & 1 & 0 & 0 & 1 & 0 & 0 & 0 & 1 & 0 & 0 & 0 & 1 \\
\hline 2012 & 0 & 0 & 1 & 1 & 0 & 1 & 0 & 1 & 1 & 0 & 1 & 1 \\
\hline 2013 & 1 & 0 & 0 & 0 & 0 & 1 & 1 & 1 & 1 & 1 & 1 & 1 \\
\hline Сумма & 6 & 4 & 5 & 4 & 3 & 9 & 5 & 8 & 5 & 5 & 8 & 8 \\
\hline \% за пентади & 46,2 & 30,8 & 38,5 & 30,8 & 23,1 & 69,2 & 38,5 & 61,5 & 38,5 & 38,5 & 61,5 & 61,5 \\
\hline \% за декади & \multicolumn{2}{|c|}{61,5} & \multicolumn{2}{|c|}{50,0} & \multicolumn{2}{|c|}{92,9} & \multicolumn{2}{|c|}{78,6} & \multicolumn{2}{|c|}{57,1} & \multicolumn{2}{|c|}{85,7} \\
\hline
\end{tabular}

Примітка: * 0 - не випадали ефективні опади; * 1 - ефективні опади випадали

\section{3. Рівень перезимівлі рослин ріпаку озимого за різних норм висіву}

\begin{tabular}{|c|c|c|c|c|c|}
\hline \multirow{2}{*}{$\begin{array}{c}\text { Строки } \\
\text { сівби }\end{array}$} & \multirow{2}{*}{ Роки } & \multicolumn{4}{|c|}{ \% перезимівлі } \\
\hline & & Сенатор люкс & Extend & DK Secure & середнє по строку \\
\hline \multirow{4}{*}{ 15-20.VIII } & $2007 / 2008$ & 73 & 56 & 54 & \multirow{4}{*}{77,7} \\
\hline & $2009 / 2010$ & 80 & 88 & 91 & \\
\hline & $2012 / 2013$ & 82 & 90 & 85 & \\
\hline & середнє & 78,3 & 78,0 & 76,7 & \\
\hline \multirow{4}{*}{ 25-31.VIII } & $2007 / 2008$ & 76 & 83 & 86 & \multirow{4}{*}{91,4} \\
\hline & $2009 / 2010$ & 95 & 97 & 98 & \\
\hline & $2012 / 2013$ & 90 & 99 & 99 & \\
\hline & середнє & 87,0 & 93,0 & 94,3 & \\
\hline \multirow{4}{*}{ 01-10.IX } & $2007 / 2008$ & 44 & 81 & 83 & \multirow{4}{*}{76,4} \\
\hline & $2009 / 2010$ & 54 & 87 & 89 & \\
\hline & $2012 / 2013$ & 58 & 95 & 97 & \\
\hline & середнє & 52,0 & 87,7 & 89,7 & \\
\hline \multirow{4}{*}{ 10-15.IX } & $2007 / 2008$ & 24 & 43 & 46 & \multirow{4}{*}{50,1} \\
\hline & $2009 / 2010$ & 32 & 55 & 63 & \\
\hline & $2012 / 2013$ & 38 & 73 & 77 & \\
\hline & середнє & 31,3 & 57,0 & 62,0 & \\
\hline
\end{tabular}




\section{СІЛЬСЬКЕ ГОСПОДАРСТВО. РОСЛИННИЦТВО}

Зазвичай у даний період верхній шар грунту після його обробітку пересушений і насіння, висіяне на глибину 2-3 см, дає нерівномірні сходи або й взагалі не проростає.

Крім того нерідко спостерігається явище «провокування проростання насіння», коли насіння, висіяне в суху землю, за випадання незначних опадів проростає, - за подальших посушливих умов відбувається засихання проростків, що в результаті призводить до строкатості сходів і погіршує перезимівлю ріпаку.

Допустимим, за фактором випадання ефективних опадів, $\epsilon$ перенесення сівби на першу декаду вересня, коли в 5-8 із 13 досліджуваних років були наявні ефективні опади, а ймовірність їх випадання знаходилася в межах 78,6 \%, однак у цей період лімітуючим фактором $\epsilon$ температурний режим. Найнижчими показниками рівня пе-

\section{БІБЛІОГРАФІЯ}

1. Інтенсивна технологія вирощування озимого ріпаку в Україні / Т. І. Лазар, О. М. Лапа, А. В. Чехов [та ін.] ; За ред. О. М. Лапа. - К. : ТОВ «Універсал-Друк», 2006. - 100 с.

2. Лихочвор В. В. Ріпак / В. В. Лихочвор, В. Ф. Петриченко. - Львів : НВФ «Українські технології», 2010. - 123 с. резимівлі $(50,1 \%)$ характеризувалися строки сівби 10-15 вересня з часткою коливання $31,3 \%$ для сорту і $62 \%$ - для низькорослого гібриду.

Найвищим рівень перезимівлі як для сорту Сенатор люкс (87\%), так і для гібридів (93 та 94,3\% відповідно) був за сівби 25-31 серпня.

Висновок. Таким чином, за результатами досліджень, проведених науковцями Кіровоградської державної сільськогосподарської дослідної станції НААН, найбільш оптимальними строками сівби ріпаку озимого в степовій зоні є період iз 25 серпня по 5 вересня, допустимо оптимальний - з 20 серпня по 10 вересня. Датою верхнього допустимого порогу оптимального строку сівби ріпаку озимого $€$ 5-10 вересня. Лімітуючий фактор у такому діапазоні - наявність вологи в грунті та випадання ефективних опадів у даний період.

3. Мороз В. М. Система первинного високоякісного насінництва ріпаку. - К., 2006. - 58 с.

4. Чехов A. В. Олійні культури в Україні / М. М. Гаврилюк, В. Н. Салатенко, А. В. Чехов; За ред. А. В. Чехова. - К. : Основа, 2007. - 416 с. 